\title{
Bladder Urothelial Papilloma
}

National Cancer Institute

\section{Source}

National Cancer Institute. Bladder Urothelial Papilloma. NCI Thesaurus. Code C39858.

A benign neoplasm of the bladder that involves the transitional epithelium projecting above the surrounding epithelial surface and consisting of villous or arborescent outgrowths of fibrovascular stroma. 